\title{
Contribution of developed countries towards MOOCs: an exploration and assessment from a representative platform Coursera
}

\author{
Arshia Ayoub, Raashida Amin and Zahid Ashraf Wani \\ Library and Information Science, University of Kashmir, Srinagar, India
}

\begin{abstract}
Purpose - The recent spate of eminence received by the MOOCs (massive open online courses) from media to academia is revolutionary in higher education. MOOCs are a disruptive technological innovation which offers open learning with the aid of the internet and delivered by the faculty of reputed institutions, globally. Since Coursera being one such significant platform, its exploration would display the broader picture of MOOCs. As a result, studying it from various dynamics has been the motive of the current endeavour.

Design/methodology/approach - The quantitative study of the collected data was applied with help of descriptive research methodology to measure the contribution of the top six countries namely US, China, Japan, Germany, India and UK. All these six countries were selected on the basis of GDP (harvested from official website World Bank - data.worldbank.org/ to Coursera - an online platform providing MOOCs. The involvement of these selected countries was gauged (from the official website of Coursera https://www.coursera.org/) in terms of number, type of contributing institutions, number of courses offered by those institutions, type of courses offered, number of instructors and instructor gender ratio.

Findings - The findings reveal that the United States (US) is the top contributor in terms of partner institutes (97), courses (Specialization courses - 1,267 and degree courses- 40) and number of instructors $(1,290)$. Interestingly, it was also observed that universities are the major contributor institutes in all six studied countries. Most of the institutes provide specialization courses while a very few provide degree courses. A large number of instructors are involved for imparting these courses online. Instructor gender ratio on average is 2:1 (male: female). It was also observed that there is usually a specific common time of starting courses on Coursera. Originality/value - Online platforms are the main delivery points for MOOCs; therefore, vibrancy and articulacy of such platforms make this innovation a success, and examining such a platform which exhibits such characteristics would present an overall picture of its functionality, development, evolution and future expansion of the innovation (MOOCs).
\end{abstract}

Keywords Online learning, Distance learning, Open education, MOOCs (massive open online courses), OER (open educational resources), ODL (open and distance learning)

Paper type Research paper

\section{Introduction}

With the changing life styles and advancements in technology, people prefer more independence in their learning process. Thus, new innovative ways of learning are evolving in the present scenario and massive open online courses (MOOCs) or online learning is one such innovative method. It provides flexible ways of teaching and learning. It provides opportunities to learn from reputed institutions and faculty regardless of one's place of living and pace of learning. Various online platforms have emerged for imparting online education which include Udacity,

(C) Arshia Ayoub, Raashida Amin and Zahid Ashraf Wani. Published in Asian Association of Open Universities Journal. Published by Emerald Publishing Limited. This article is published under the Creative Commons Attribution (CC BY 4.0) license. Anyone may reproduce, distribute, translate and create derivative works of this article (for both commercial and non-commercial purposes), subject to full attribution to the original publication and authors. The full terms of this license may be seen at http:// creativecommons.org/licences/by/4.0/legalcode.

Contribution of developed countries towards MOOCs

Received 22 April 2020

Revised 11 June 2020 28 July 2020

5 August 2020

5 August 2020

11 August 2020

Accepted 12 August 2020 
AAOUJ

15,2

edX, Coursera, etc. This study is an attempt to gauge the contribution of top six countries (on basis of GDP) in one such platform - Coursera. Various MOOC platforms are evolving worldwide for the promotion of online learning. Thus, in the present study, one of the important platforms of online Learning-Coursera is being explored. Coursera provides universal access to the world's best education by partnering with top universities and organisations.

As technology has liberated the process of learning and teaching, geographical boundaries stand no more a hurdle in imparting and receiving quality education. The technological creation of a global learning environment is making it possible to access the study material from anywhere at any time. Apart from expansion of technology-inclusive growth, economic liberalisation and globalisation, popularity of global-lifelong learning as well as blended learning are some basic reasons for the emergence of open and distance learning (ODL) and as such ODL is gaining momentum at an unprecedented pace (Bordoloi, 2018; Wong et al., 2016). Online education has changed the perspective of the learning process. Informal learning through interrogation of digital resources by adults and children outside educational institutions is the new trend of the current era (Tait, 2018). This may also lead to curriculum innovation which is more cooperatively developed and learner led. Online education is simply imparting education, which includes both teaching and providing course material to the learners via the internet (Cavanaugh et al., 2009). Since recent years this new form of online education has gained popularity which is simply considered as an online mode of distance education and is being offered through MOOCs (Sharma et al., 2017). McAuley et al. (2010) stated that "A MOOC is an online course with the option of free and open registration, a publicly shared curriculum, and open-ended outcomes". According to Voss (2013), "MOOCs use web-based tools and environments - referred to as platforms - to deliver education and classes in a new paradigm without regard for geographic boundaries and time zones and to much larger audiences". David Cormier, in 2008, introduced the term MOOC and in the same year got commenced by the creation of course Connectivism and Connected Knowledge by George Siemens and Stephen Downes (McAuley et al.,2010) and is considered as the first MOOC initiative. The idea got a massive push in 2011, when elite institutions like University of Pennsylvania, Princeton University, Stanford University and the University of Michigan and in 2012 Massachusetts Institute of Technology and Harvard University got united and initiated to deliver free courses online (Voss, 2013).

During the period 2012-2013, universities around the world accepted this (MOOC) approach of imparting education. Thus, various firms evolved the infrastructure for providing MOOCs (Baggaley, 2013). These platforms offer education at the doorsteps and allow knowledge seekers to learn and get educated from some of the elite institutions, over the web. The basic technological requirements for every $\mathrm{MOOC}$ include - high quality indexed video, data capture and analytics and delivery platforms (EDUCAUSE Executive Briefing, 2012). Online learning through MOOCs provides a flexible and open environment for unlimited participation and the motivations that drive students to learn include support for distance and life-long learning, enjoyment and entertainment, intellectual stimulation, ease of use and to get involved and explore e-education (Belanger and Thornton, 2013). MOOCs have the ability of bringing significant changes in the traditional educational system (Sharples et al., 2012). Based on the varied nature and characteristics, MOOCs have been classified in a number of ways. A simple classification comprises - XMOOCs- where content interaction and behaviourist learning approach is of key importance and constitute recent initiatives such as Edx, Cousera and Udacity and CMOOCs where social media utility and peer connectivity is of prime importance thus following the connectivist learning approach (Conole, 2013). xMOOCs are based on a very primitive behaviourist pedagogy committed for information transmission (Bates, 2012) but cMOOCs are rooted in connectivism (Kop and Hill, 2008; Siemens and Downes, 2008), a sophisticated and innovative reconceptualisation of what it means to know and to learn (Clow, 2013).

A large number of platforms offer such online courses and allow institutions to deliver courses through cloud based hosting (Czerniewicz et al., 2015). From amongst diverse MOOC 
platforms Coursera, Edx and Udacity are considered as pioneer ones which provide multitude of courses and get beyond 100,000 registrations for each course (Seaton et al., 2014). Among these Udacity was founded in February 2012 by a Stanford University computing professor (DeSantis, 2012). After a few months in April 2012, two other Stanford computing professors launched Coursera. By June 2013, Coursera had agreements with 70 higher education partners including prestigious institutes like Stanford and Princeton. Another important MOOC platform edX was launched in May 2012 by Harvard University and Massachusetts Institute of Technology (MIT), led by an MIT computing professor and by June 2013, it was serving 28 partners (Baggaley, 2013; edX, 2013). Among these top platforms, Coursera is considered the world's largest online learning platform for higher education, hence, suitably selected as a representative $\mathrm{MOOC}$ platform for the purpose of exploring the contribution of top five countries (on basis of GDP) in the current study. The MOOCs platform Coursera, founded in 2012 by two Computer Science Professors from Stanford University - Daphne Kollar and Andrew Ng, offers online courses delivered by the institutions and organizations of its partner countries including some of the prestigious universities and education providers, empowering more than 40 million learners from across the globe (Coursera, 2019).

\section{Literature review}

Like any other sector, technology onslaught has transformed the system of education too. The Internet has paved the way for open learning. Open learning movements like Open Educational Resources (OERs) and Massive Open Online Courses (MOOCs) have gained momentum and reputation to such an extent that present era has been termed as "higher education's digital moment" (Hamber et al., 2015) where OERs are "teaching, learning and research resources that reside in the public domain or have been released under an intellectual property licence that permits their free use and re-purposing. OERs include full courses, course materials, modules, text-books, streaming videos, tests, software and any other tools, materials or techniques used to support access to knowledge" (Hewlett Foundation, 2005). Since the emergence of these initiatives particularly MOOCs and MOOCs platforms, their area has been much intriguing for researchers because of their instant fame and future revolutionary consequences. Fox (2013) considered MOOCs as a "new technology opportunity whose potential pedagogical impact needs to be researched. He argued that MOOCs themselves can yield valuable information because of their scale and that MOOC materials can be used in a blended small private online course setting to supplement the classroom experience".

The survey of the literature suggests that most studies in the area of MOOCs have been conducted from the perspective of learners with scant research available on various MOOC platform explorations and assessments, therefore, making its study in the area pertinent. Accordingly, a brief overview of the studies conducted that pertain to various aspects of these initiatives is given next.

Hollands and Tirthali (2014) suggested that MOOCs can bring revolutionary change as these have "potential to catalyze the development of true adaptive learning experiences". But they stressed that it can be achieved through significant investment in resources, institutional collaborations and alterations in rules for better use and sharing of data. But, as far as capitalizing investments is considered, Pouezevara and Horn (2016) stress that developing economies should not drain away their attention and resources from well functional online universities which impart best and low-cost education and invest it on "MOOCs for development" projects. Rather development partners should take the support measures to meet their demands for MOOCs. Besides, MOOCs should be made successful by both regional and international partnerships. Chen (2013) conducted a study on various dimensions like origin and trends in MOOCs with further elaboration on the opportunities and challenges posed by MOOCs, with a focus on Asian countries. This study stresses that MOOCs will address the
Contribution of developed countries towardsMOOCs

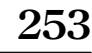


AAOUJ

15,2

demand of higher educational institutions in developing countries, increase rate of information literacy, prove a medium of life-long learning and offers chances of discovery of course material irrespective of boundaries while challenges posed include - diminished enrolments in Asian universities, elevated load of running universities, need of increased technological literacy among teachers and language proficiency. Hamber et al. (2015) in a study conducted on various dimensions of different MOOC platforms also assessed the Coursera course distribution by subject and found that humanities, computing and business dominate with $14 \%$ and $17 \%$ of courses while science, health and education each comprise almost $10 \%$ of the courses. The study further notes that most of the learners registered with MOOCs, belong to the developed nations which amounts to justify the delivery of the majority of courses in English language followed by Spanish. In yet another study, conducted by Baturay (2015), findings reveal that the majority of students enrolled in Coursera are international with a great deal of demand for science and technology courses from the Indian students.

Paddick (n.d.) in a study while quoting Maria Garrido, research assistant professor at Technology and Social Change Group (TASCHA) at the University of Washington's information school, revealed that many students from the developing nations that get enrolled in the MOOCs belong to low and middle income backgrounds. Further, the completion and certification of courses was seen higher for students from developing economies than from the developed world. The study confirmed the individual course completion rates in the US and Europe just between $5 \%$ and $10 \%$. The survey revealed that the users from developing countries tended to have higher completion rates because of their need for advancement of education and career development while those from advanced economies reported their enrolment mostly for "personal fulfilment" with more preference for the sake of enjoyment. Similarly, Hakami et al. (2017) conducted a survey of literature published between 2011 and 2016 to determine the motivations that drive learners towards MOOCs and their geographic distribution. The study traced learner related factors such as personal, social and professional development; institution and teacher related like reputation of the institution; platform and course delivered factors like beneficial, easy-access, open-access, information quality, customization, etc. as the motivating factors. Wang and Baker (2015) studied the student behaviour towards MOOCs, for which the learners registered with the course "Big data in Education" offered through Coursera were surveyed through emails. The findings signify different goals behind different learner behaviours as course-content was seen to be the main motivation for course-completers while for drop-outs got interest because of the new and innovative learning platform.

Clow (2013) conducted a study based on three online learning sites namely Ispot, cloudworks and openED 2.0 to investigate the issue of learner drop-outs in MOOCs. The findings conclude that MOOCs witness a steep drop-outs and unequal participations for which the paper introduces the term "funnel of participation" which describes the learner process of MOOC engagement as beginning from awareness and registration followed by activity and the progression where the drop-out at each stage has been noticed significant. But some researchers are of the view that this is a positive sign of an exploratory phase of MOOCs (Rosen, 2012). There are also studies that tried to assess the instructional quality of MOOCs and observed that there is limited implementation of instructional design principles within MOOCs but organization and presentation of course material is done in good style (Margaryan et al., 2015). They further proposed three potential causes for the observed facts that include the following:

(1) Lack of knowledge regarding contemporary instructional design principles or learning theories.

(2) Inability to use these theories in MOOCs despite of being aware of said theories.

(3) Driven predominantly by institutional marketing considerations rather than by pedagogical concerns. 
Li and Baker (2016) in a study conducted on the data from one Coursera course "pre-calculus" hosted by University of California and recorded number of lectures watched as denoting learner behavioural engagement and count of pauses in the watched lectures as representation of cognitive engagement. The findings reveal that a significant proportion of learners having behavioural interactions were found to have no cognitive engagement i.e. the pauses in watching lectures were either less in number or not at all, indicating no relation between the two engagement patterns. Thus, stressing the need to study both the engagements in order to know the learner activity. The study also found learner lecture pauses having a positive relation with the learner achievements. Another study conducted by Emanuel (2013) explored the educational levels of learners enrolled in the Coursera course delivered by the University of Pennsylvania. The study found that the majority of learners involved in the courses has already attained higher education with graduates comprising $83 \%$ and post-graduates $44.2 \%$.

Singh and Chauhan (2017) undertook a study to gauge the familiarity and awareness of educators pertaining to MOOCs usage in teacher education and development, for which 156 teacher educators were surveyed pertaining to - awareness about MOOCs, use, innovation, practices and policies. The study found that educators share the basic knowledge about the MOOCs, course delivery mode and utility. The study concluded that besides providing a broad and clear picture of MOOCs to teacher educators, they should be given opportunities to develop, integrate and incorporate this innovation in daily classroom practices. Laurillard (2016) undertook a study in collaboration with UNESCO Institute for IT in Education (IITE) to investigate the role of MOOCs in continuing professional development (CPD) for which a course was initiated on Coursera to gauge its efficiency for teachers in need of CPD but unable to receive it, and the data was collected using course analytics, forums and participant surveys. The study found that most of the MOOCs enrolments comprise the qualified professional learners thus demystifying the belief that disadvantaged learners mostly get the benefit from MOOCs. Further, the study concludes that development of primary level teachers can be well addressed using this innovation. Silvia (n.d.) studied the perspective of teachers towards professional development courses as delivered by Coursera for which the data was gathered from the course Foundation of Teaching for Learning 1: Introduction course. The survey reveals that participants perceive the course effectively structured and organized and the contents assisted them to upgrade their teaching skills.

Thus, it can be deduced that learners, specifically the employed and professionals, can benefit hugely from the MOOCs, mostly from one's delivered by developed nations, provided the challenges are met. Besides, developing countries need to improve their own platforms with support from developed economies. Accordingly, this study would try to gauge the involvement of developed nations in the said initiative and their role in advancement of education through MOOCs.

\section{Scope}

The scope of this study was limited to the Coursera which provides the platform for online education. It is an American online learning platform that partners with top universities and organizations worldwide. Further, the study was limited to those six partner countries of Coursera that have the highest GDP as per data provided by the World Bank.

\section{Objectives}

The objectives of the study are

(1) To gauge the number and type of institutions of selected countries hosting courses.

(2) To determine the number of courses offered by the institutions with their time of availability. 
AAOUJ

15,2

(3) To measure the number and gender type of instructors participating in development of MOOCs.

Thus, the study attempts to bring forth the contribution of selected countries in implementation of MOOCs.

Methodology

The descriptive research methodology was employed for the study. Official websites of the World Bank (https://www.data.worldbank.org/) and Coursera (https://www.coursera.org/) were browsed, explored on 16 May 2020. The relevant data was only collected and harvested in the current study. The overall data collection comprised following steps:

(1) As better economic performance leads to greater educational participation and achievements, for the current endeavour, GDP (gross domestic product) of the top five countries were traced from the official website of The World Bank (www.data.worldbank. org/). The World Bank website provides free and open access to the global development data which include indicators about development of countries. The countries traced in the decreasing order of their GDP include - US (21.4 trillion), China (14.14 trillion), Japan (5.15 trillion), Germany (3.86 trillion), India (2.94 trillion) and UK (2.83 trillion).

(2) Then, the official website of Coursera was explored from its community section which comprises learners, partners, developers, translators, etc. Not only the "Partners" category was browsed for assessing and gauging the country-wise contributions but also other parameters as well. As on 16-5-2020, Coursera has 212 partners across 50 countries which offer 4,558 courses. The countries selected for the exploration were probed individually from the "All Countries and Regions" list.

(3) Under each country page, all its participating institutes are listed. Links of each participating institute were individually browsed where names of courses offered are provided and also names of instructors with their pictures are provided at the bottom of the page.

(4) Thus for each selected country the data pertaining to their contributions - number of institutions/organizations/associations offering courses, under each institution number of courses offered, course type, course start date, instructors involved, gender ratio of instructors, etc. are specified for every institution on the website was collected manually in the excel file. The collected data was tabulated, analysed and interpreted as per the set objectives.

\section{Data interpretation}

(1) Number and Type of Partner Institutes

Coursera provides universal access to the world's best education, partnering with top universities and organizations to offer courses online. The data collected depicted the maximum number of institutes among six countries, with highest GDP (as per data of World Bank), which participate in Coursera belonging to the United States (97) followed by China (7) and UK (7). Germany (3) and India (3) occupy the third place while Japan comes last with only one institute. It was analysed that among participating institutes, the majority were universities as shown in the table below. It was also observed that not even a single university of India is participating on the Coursera platform. The other types of institutes which take part in Coursera are associations etc. hence represented by the "others" column in the table. 
Table 1 offers a lucid picture and shows the United States is the leading country in MOOC development which is in tune with its economy and educational achievements but it is quite shocking other leading economies are not in the same league or somewhere near it. This reflects highly on the priorities of these countries or their inability to adopt new technologies quickly and promptly for their own development particularly when it comes to the educational domain. All nations of Globe should also try to follow the same trend as depicted by the US to boost the MOOCs implementation in their respective nations and should encourage their educational institutions particularly their universities to implement such initiatives which would help them to transform and empower their education sector. It would also help people in securing employment or people with family responsibilities to complete their degrees through informal or non-traditional ways.

\section{(2) Number of Courses and Contributing Institutes}

A large number of courses are being provided through Coursera by the participating institutes of the selected countries. The US tops the list with 1267 courses while China has attained second position with 88 courses. UK (84) has acquired third place followed by Germany (12), Japan (6) and India (5). Among the 97 participating institutes of the US, the highest number of courses is being offered by University of Illinois with 76 specialization courses and 5 degree/certificate courses followed by University of Pennsylvania $(62+1)$. Interestingly there were only two institutes (that belonged to the US) that do not contribute any courses at present namely, National Geographic society and CertNexus. Peking University (46) is the top contributing institute of China while in the UK, University of London (31) offers the highest number of courses. Japan has only one contributing institute, The University of Tokyo that offers 6 courses while has three participating institutes viz., Indian Institute of Human Settlements, Indian Institute of Management Calcutta (IIMC) and Indian School of Business (5). Germany has three participating institutes viz., Technische Universität München (8), Karlsruhe Institute for Technology and Ludwig-MaximiliansUniversität München (7). Thus, US (particularly its universities) again are acting as the point of reference for all nations as these provide a large number of courses (both specialization and degree) that provide the candidates wider options so that they can opt the courses of their choice that may help them to have better options for achieving their career goals (see Table 2).

(3) Number of courses offered by selected countries

Various types of $\mathrm{MOOC} /$ online courses are being offered on Coursera that include specialization courses, professional courses and degree courses. Maximum number of institutes provide specialization courses while few provide professional and degree courses. US is the leading provider of both specializations $(1,267)$ as well as Degree/certificate courses (40) followed by China (88) and UK (81 specialization courses, 3 degree courses) while Germany (11), Japan (6) and India (5) provide only specialization courses. The trend towards specialized courses is obvious and rightly so due to their job oriented nature. World needs more specialists for catering different industries and social dimensions for maintaining proper equilibrium and

\begin{tabular}{lccr}
\hline Countries & Total no. of partner institutes & No. of universities & Others \\
\hline United States & 97 & $48(\sim 50 \%)$ & 49 \\
China & 7 & $7(100 \%)$ & 0 \\
Japan & 1 & $1(100 \%)$ & 0 \\
Germany & 3 & $3(100 \%)$ & 0 \\
India & 3 & 0 & 3 \\
United Kingdom & 7 & $4(\sim 57 \%)$ & 3
\end{tabular}

Contribution of developed countries towards MOOCs

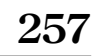 \\ 257}


AAOUJ 15,2

\section{8}

speeding up the process of development. Development of need-based and skill-based courses should be the main focus for developing economies as they have direct connection with industrial and vocational recruitments (see Table 3).

\section{(4) Number of instructors and gender differentiation}

A large number of instructors are involved/engaged in imparting online education to people. As the US is providing the maximum number of courses, the number of instructors involved in providing online education is also highest $(1,290)$, followed by the UK (141) and China (138). The fourth position is occupied by Germany (15) followed by Japan (9). Each country has more male instructors than females. Thus, the male-female ratio of instructors on average turned as 2:1 as is

\begin{tabular}{|c|c|c|c|}
\hline Countries & $\begin{array}{l}\text { Total no. of } \\
\text { courses }\end{array}$ & $\begin{array}{c}\text { Total no. of participating } \\
\text { institutes }\end{array}$ & Name of institutes \\
\hline United States & 1307 & 97 & $\begin{array}{l}\text { University of Illinois }(76+5) \\
\text { University of Pennsylvania }(62+1) \\
\text { Duke University }(46) \\
\text { Google Cloud }(95+3) \\
\text { Johns Hopkins University }(57) \\
\text { University of Michigan }(57+6) \\
\text { University of Colorado Boulder }(45) \\
\text { University of Virginia (38) } \\
\text { University of California, San Diego (35) } \\
\text { University of California, Irvine }(41+1)\end{array}$ \\
\hline China & 88 & 7 & $\begin{array}{l}\text { Peking University (46) } \\
\text { Nanjing University (16) } \\
\text { Shanghai Jiao Tong University (10) } \\
\text { Fudan University (6) } \\
\text { Xi'an Jiaotong University (6) } \\
\text { Tsinghua University (2) } \\
\text { University of Science and Technology of China } \\
\text { (2) }\end{array}$ \\
\hline Japan & 6 & 1 & The University of Tokyo \\
\hline Germany & 11 & 2 & $\begin{array}{l}\text { Technische Universität München (8) } \\
\text { Karlsruhe Institute for Technology } \\
\text { Ludwig-Maximilians-Universität München (7) }\end{array}$ \\
\hline India & 5 & 3 & $\begin{array}{l}\text { Indian Institute of Human Settlements } \\
\text { Indian Institute of Management Calcutta } \\
\text { Indian School of Business (5) }\end{array}$ \\
\hline $\begin{array}{l}\text { United } \\
\text { Kingdom }\end{array}$ & 84 & 7 & $\begin{array}{l}\text { University of London (31) } \\
\text { The University of Edinburgh (28) } \\
\text { Commonwealth Education Trust (10) } \\
\text { University of Manchester (8) } \\
\text { Imperial College London (5) } \\
\text { PwC (1) } \\
\text { University of Leeds (1) }\end{array}$ \\
\hline
\end{tabular}

Table 2.

Number of courses and contributing institutes

\begin{tabular}{lrc}
\hline Countries & No. of specialization courses & No. of degree/Professional courses \\
\hline United States & 1267 & 40 \\
China & 88 & 0 \\
Japan & 6 & 0 \\
Germany & 11 & 0 \\
India & 5 & 0 \\
United Kingdom & 81 & 3
\end{tabular}


clear from data. The gender bias is still evident even in the 21st century that too in world's leading economies. Still less than $40 \%$ females are involved as instructors. Japan's lowest female ratio is evident from the table below. Hopefully, these figures will improve over time (see Table 4).

(5) Course availability

It was found from the data, the most courses from all these countries begin during the common specified time, particularly from the month of July. The US provided its (961) courses in the month of July while few courses were offered during August (12) and other months (9). The UK also offered most of its courses (79) during July and only 2 courses were provided in August while China, Japan, India and Germany offer all the courses during the month of July. The possible reason behind this can be the fact that July is the month of summer vacations in the northern hemisphere of the globe, thus most people are having free time during this month. This can boost the participation in all the courses offered by these institutions and thus benefiting learners to make the most of their free time. Also the importance of this month cannot be overlooked by policymakers as it will enhance the number of participants in their MOOCs endeavours. For Degree courses, the course starting time is according to the session of the individual institute that offers the course. Table 5 offers a detailed picture.

\section{Conclusion}

The study reveals the position of the selected countries in adopting and incorporating technological innovations in the educational sector. The countries, selected on the basis of GDP, were expected to have technological advancements and involvements in imparting education in line with their GDPs, but, the findings, intriguingly, reveal that United Kingdom, with the lowest GDP among the six countries, seconds the list and stands almost with China in all the areas investigated by the study. The position of China, unexpectedly, is not so exemplary, as gauged from their contributions to MOOC platform Coursera. Japan and Germany, despite being highly developed countries, seem to have resisted the innovation in the educational sector. Such nations must reform their educational systems and infuse technological innovations which, besides acting as a catalyst for the education sector, could also enable learners from developing countries to avail the benefit by economically accessing the quality education over the internet. This way top five will not only benefit their own population but will also contribute to global educational endeavours especially can be a boon for third world countries for the upliftment of their education which eventually would act as a robust factor for change, upgrade livelihoods, foster

\begin{tabular}{lrrrr}
\hline Countries & Total no. of instructors & No. of males & No. of females & \\
United States & 1290 & $872(67.60 \%)$ & $418(32.40 \%)$ & \\
China & 138 & $92(66.67 \%)$ & $46(33.33 \%)$ & $1(11.11 \%)$ \\
Japan & 9 & $8(88.89 \%)$ & $5(33.33 \%)$ & Number of instructors \\
Germany & 15 & $10(66.67 \%)$ & $1(11.11 \%)$ & and gender \\
India & 9 & $8(88.88 \%)$ & $54(38.30 \%)$ & differentiation \\
United Kingdom & 141 & $87(61.70 \%)$ & & \\
\hline
\end{tabular}

\begin{tabular}{lcrrrrrr}
\hline Starting time of courses & United States & China & Japan & Germany & India & United Kingdom \\
\hline No. of courses starting in July & 961 & 88 & 6 & 11 & 5 & 79 \\
No. of courses starting in August & 12 & 0 & 0 & 0 & 0 & 2 & Table 5. \\
No. of courses starting afterwards & 9 & 0 & 0 & 0 & 0 & Course availability \\
\hline
\end{tabular}

Contribution of developed countries towards MOOCs

259 
AAOUJ 15,2

social stability and reduce poverty. This if given proper focus may lead to global economic and social development that can eventually lead to peaceful co-existence at global level. This can be defined through two strategies- one, higher education acting as a soft power tool- wherein countries influence others and attain national self-interests through pleasing and persuading others instead of compulsion, oppression, military force, etc. Second, knowledge diplomacy which is currently being endorsed for strengthening international relations between nations through generation, dissemination and exchange of knowledge (Knight, 2016), thus, promoting peace and fostering development.

Additionally, the exemplary contribution of the US may also be attributed to the fact that the US spends approximately $6.2 \%$ of its GDP on education (Investopedia, 2019) that has helped in the tremendous development of this sector. The other countries (China, Japan, Germany, India and UK) lag behind, though Germany (5.5\%) spends the highest percentage of its GDP among these five. Majority of the courses imparted by all of these nations were specialization courses. This can be credited to the fact that such courses increase the probability of getting a job and become independent in financial terms.

Besides, a feature noticed in all the course contributions of all the studied countries was a specific time-set for the course delivery i.e. almost all the contributing institutions prefer synch MOOCs. Such time issues create bottlenecks in acquiring MOOC studies which is preferably a pastime learning besides creating a hurdle in synchronizing the time variations of different zones. Therefore, such issues of time, cost, language etc. that restrict their utility and reinforce learner drop-out should be resolved. Developed economies need to take the lead in removing the barriers in providing universal access to education. Open educational platforms like MOOCs must be upgraded and rated at par with the traditional learning. They should offer some scholarship programmes too in the MOOCs studies. Besides, they need to extend their support to developing countries in instituting and promoting such initiatives by providing financial, technical and intellectual assistance.

There are limitations to this study. It is confined to only one but largest MOOC platform Coursera. Thus the findings cannot be generalised and may vary over other platforms. In future studies the scope of study should be widened to include other platforms of MOOCs.

\section{References}

Baggaley, J. (2013), “MOOC rampant”, Distance Education, Vol. 34 No. 3, pp. 368-378, doi: 10.1080/ 01587919.2013.835768.

Bates, T. (2012), "What's right and what's wrong about coursera-style MOOCs", available at: http:// www.tonybates.ca/2012/08/05/whats-right-and-whatswrong-about-coursera-style-moocs/ (accessed 15 january 2020).

Baturay, M.H. (2015), "An overview of the world of MOOCs", Procedia-Social and Behavioral Sciences, Vol. 174, pp. 427-433, doi: 10.1016/j.sbspro.2015.01.685.

Belanger, V. and Thornton, J. (2013), Bioelectricity: A Quantitative Approach-Duke University's First MOOC, available at: https://dukespace.lib.duke.edu/dspace/bitstream/handle/10161/6216/Duke_ Bioelectricity_MOOC_Fall2012.pdf (accessed 28 December 2019).

Bordoloi, R. (2018), "Transforming and empowering higher education through open and distance learning in India", Asian Association of Open Universities Journal, Vol. 13 No. 1, pp. 24-36, doi: 10.1108/AAOUJ-11-2017-0037.

Cavanaugh, C.S., Barbour, M.K. and Clark, T. (2009), "Research and practice in K-12 online learning: a review of open access literature", International Review of Research in Open and Distance Learning, Vol. 10 No. 1, pp. 1-22, available at: http://www.irrodl.org/index.php/irrodl/article/ view/607/1183.

Chen, J.C. (2013), "Opportunities and challenges of MOOCS: perspectives from Asia”, IFLA WLIC 2013, available at: http://library.ifla.org/157/1/098-chen-en.pdf. 
Clow, D. (2013), "April. MOOCs and the funnel of participation", Proceedings of the Third International Conference on Learning Analytics and Knowledge, pp. 185-189, doi: 10.1145/2460296.2460332.

Conole, G.G. (2013), "MOOCs as disruptive technologies: strategies for enhancing the learner experience and quality of MOOCs", Revista de Educación a Distancia, No. 39, pp. 1-17, available at: https://revistas.um.es/red/article/view/234221.

Coursera (2019), "Press", available at: https://about.coursera.org/press.

Czerniewicz, L., Deacon, A., Fife, M., Small, J. and Walji, S. (2015), CILT Position Paper: MOOCs, CILT, University of Cape Town, available at: https://www.academia.edu/37387104/MOOCs_CILT_ POSITION_PAPER.

DeSantis, N. (2012), "Stanford professor gives up teaching position, hopes to reach 500,000 students at online start-up", The Chronicle of Higher Education, available at: http://chronicle.com/blogs/ wiredcampus/stanford-professor-gives-up-teaching-position-hopes-to-reach-500000-students-atonline-start-up/35135.

EDUCAUSE Executive Briefing (2012), "What campus leaders need to know about MOOCs", available at: https://oerknowledgecloud.org/sites/oerknowledgecloud.org/files/PUB4005\%20pdf.pdf.

edX (2013), Creating Better Schools for the Campus and the World, available at: https://www.edx.org/ schools.

Emanuel, E.J. (2013), “Online education: MOOCs taken by educated few”, Nature, Vol. 503 No. 342, doi: $10.1038 / 503342 \mathrm{a}$.

Fox, A. (2013), "From MOOCs to SPOCs", Communications of the ACM, Vol. 56 No. 12, pp. 38-40, doi: $10.1145 / 2535918$.

Hakami, N., White, S. and Chakaveh, S. (2017), "Motivational factors that influence the use of MOOCs: learners' perspectives - a systematic literature review", Proceedings of the 9th International Conference on Computer Supported Education (CSEDU 2017), Vol. 2, pp. 323-331, doi: 10.5220/ 0006259503230331.

Hamber, B., Jaffrey, A. and Murphy, B. (2015), "MOOCs and open learning at ulster university: research, consultation and recommendations on an institutional approach", available at: https:// pure.ulster.ac.uk/ws/files/11532536/report-MOOC_Ulster_2015.pdf.

Hewlett Foundation (2005), Open Educational Resources Initiative, available at: http://www.hewlett. org/programs/education/open-educational-resources.

Hollands, F.M. and Tirthali, D. (2014), MOOCs: Expectations and Reality, Vol. 138, Center for BenefitCost Studies of Education, Teachers College, Columbia University, available at: https://www. researchgate.net/profile/Devayani_Tirthali/publication/271841177_MOOCs_Expectations_ and_reality/links/54d3c7dc0cf2970e4e603eb3.pdf.

Investopedia (2019), "What country spends the most on education?”, available at: https://www.investopedia. com/ask/answers/020915/what-country-spends-most-education.asp (accessed 23 January 2020).

Knight, J. (2016), "International education, global understanding”, available at: https://www.deutschland. de/en/topic/knowledge/networks-partnerships/international-education-global-understanding.

Kop, R. and Hill, A. (2008), “Connectivism: learning theory of the future or vestige of the past?", The International Review of Research in Open and Distributed Learning, Vol. 9 No. 3, available at: http://www.irrodl.org/index.php/irrodl/article/view/9.3.4.

Laurillard, D. (2016), "The educational problem that MOOCs could solve: professional development for teachers of disadvantaged students", Research in Learning Technology, Vol. 24, doi: 10.3402/rlt. v24.29369.

Li, Q. and Baker, R. (2016), "Understanding engagement in MOOCs", Proceedings of the 9th International Conference on Educational Data Mining, pp. 605-606, available at: https://pdfs. semanticscholar.org/5811/700b27934fbla432f0f7cf8da5822c30920f.pdf.

Margaryan, A., Bianco, M. and Littlejohn, A. (2015), "Instructional quality of massive open online courses (MOOCs)", Computers and Education, Vol. 80, pp. 77-83, doi: 10.1016/j.compedu.2014. 08.005 .
Contribution of developed countries towardsMOOCs 
AAOUJ 15,2

\section{2}

McAuley, A., Stewart, B., Siemens, G. and Cormier, D. (2010), The MOOC Model for Digital Practice, available at: https://www.researchgate.net/profile/Alexander_Mcauley/publication/260205419_ The_MOOC_model_for_digital_practice/links/00b4953025b00756fe000000.pdf.

Paddick, R. (n.d.), "How MOOCs are used around the world", available at: https://How MOOCs are used around the world-Education Technology.html.

Pouezevara, S. and Horn, L. (2016), "MOOCs and online education: exploring the potential for international educational development", RTI Press, doi: 10.3768/rtipress.2016.OP.0029.1603.

Rosen, R.J. (2012), "Overblown-Claims-of-Failure watch: how not to gauge the success of online courses", The Atlantic, available at: http://www.theatlantic.com/technology/archive/2012/07/ overblown-claims-of-failure-watch-how-not-to-gauge-thesuccess-of-online-courses/260159/.

Seaton, D.T., Bergner, Y., Chuang, I., Mitros, P. and Pritchard, D. (2014), "Who does what in a massive open online course?", Communications of the ACM, Vol. 57 No. 4, pp. 58-65, doi: 10.1145/2500876.

Sharma, A.K., Gaurav, K. and Hosamani, H. (2017), "MOOCS in Indian higher education system: an overview", available at: https://www.researchgate.net/publication/312625111_MOOCS_in_ Indian_Higher_Education_System_An_Overview.

Sharples, M., McAndrew, P., Weller, M., Ferguson, R., FitzGerald, E., Hirst, T., Mor, Y., Gaved, M. and Whitelock, D. (2012), Innovating Pedagogy 2012: Open University Innovation Report 1, The Open University, Milton Keynes.

Siemens, G. and Downes, S. (2008), "Connectivism and connected knowledge: CCK08, CCK09", available at: http://tc.umanitoba.ca/connectivism/.

Silvia, A. (n.d.), “Coursera online courses for efl teachers' professional development”, available at: file:///C:/Users/dell/Downloads/COURSERA_ONLINE_COURSES_FOR_EFL_TEACHERS.pdf.

Singh, G. and Chauhan, R. (2017), "Awareness towards massive open online courses (MOOCs) and their usage for teacher education in India”, The Asian Society of Open and Distance Education, Vol. 12 No. 2, pp. 81-88, available at: http://www.asianjde.org/2017v12.2.Singh.pdf.

Tait, A. (2018), "Open Universities: the next phase", Asian Association of Open Universities Journal, Vol. 13 No. 1, pp. 13-23, doi: 10.1108/AAOUJ-12-2017-0040.

Voss, B.D. (2013), "Massive open online courses (MOOCs): a primer for university and college board members", available at: https://eric.ed.gov/id=ED549761.

Wang, Y. and Baker, R. (2015), “Content or platform: why do students complete MOOCs?”, MERLOT Journal of Online Learning and Teaching, Vol. 11 No. 1, available at: http://jolt.merlot.org/ vol11no1/Wang_0315.pdf.

Wong, Y.Y., Zeng, J. and Ho, C.K. (2016), "Trends in open and distance learning research: 2005 vs 2015”, Asian Association of Open Universities Journal, Vol. 11 No. 2, pp. 216-227, doi: 10.1108/ AAOUJ-09-2016-0035.

\section{Corresponding author}

Arshia Ayoub can be contacted at: arshiaayoub786@gmail.com

For instructions on how to order reprints of this article, please visit our website:

www.emeraldgrouppublishing.com/licensing/reprints.htm

Or contact us for further details: permissions@emeraldinsight.com 